\title{
Analisis Survival pada Data Pasien Covid 19 di Kabupaten Jember
}

\author{
(Survival Analysis on Covid 19 Patients Data in Jember Regency) \\ Bella Audina \& Mohamat Fatekurohman*) \\ Jurusan Matematika, Fakultas Matematika dan Ilmu Pengetahuan Alam, Universitas Jember \\ Jl. Kalimantan 37, Jember 68121 \\ *)Penulis Korespondensi E-mail: mfatekurohman.fmipa@unej.ac.id
}

\begin{abstract}
The confirmed number of positive Covid 19 cases in Indonesia until June 15th, 2020 was 38.227 people with 3.134 dead, case fatality rate 5,9\%. Case fatality rate is the percentage of the number of dead people from all confirmed and reported positive cases. Particularly, in Jember Regency, the spreading of Covid 19 is still underway day by day with the increasing of number of patient so that appropriate preventive and treatment should be done precisely. The problem of the paper is the survival analysis of Covid 19 patient by using Kaplan Meier and Log Rank test method. The result of this paper, the result of the analysis using Kaplan Meier Curve method, patients with male sex have a chance of recovering faster compared with female patients and patients with age interval of 40-49 years have a chance of recovering faster than any other age intervals, meanwhile Log rank test did not provide significant results. So the Kaplan Meier Curve method is more appropriate to analyze Covid 19 patient data in Jember compared to the Log rank test.
\end{abstract}

Keywords: Survival Analysis, Covid 19, Kaplan Meier, Log Rank.

\section{PENDAHULUAN}

Penyakit baru di awal tahun 2020 yang berhasil menggemparkan dunia disebut Coronavirus disease 2019 (COVID 19). Virus yang menyebabkan penyakit ini yaitu Corona atau severe acute respiratory syndrome coronavirus 2 (SARS-CoV-2), dimanan virus ini menyerang sistem pernapasan. Gejala yang ditimbulkan apabila terinfeksi Covid 19 terbagi menjadi tiga jenis yaitu gejala ringan, sedang, dan berat. Gejala ringan atau yang sering disebut gejala awal bisa berupa penyakit flu. Gejala sedang bisa meyebabkan infeksi paru-paru (pneumonia). Ketiga gejala tersebut dapat sembuh atau bahkan dapat menyebabkan kematian pada penderitanya [1].

Virus Covid 19 hampir merebak ke seluruh dunia. Kasusnya setiap hari kian bertambah, salah satu kasusnya dapat kita jumpai di Indonesia. Berdasarkan data yang dirilis Gugus Tugas Percepatan Penanganan Covid 19 Republik Indonesia, jumlah kasus terkonfirmasi positif hingga 15 Juni 2020 adalah 38.227 orang dengan jumlah kematian 3.134 orang. Dari kedua angka ini dapat disimpulkan bahwa case fatality rate atau tingkat kematian yang disebabkan oleh Covid 19 di Indonesia yaitu sekitar $5,9 \%$. Case fatality rate adalah presentase jumlah kematian dari seluruh jumlah kasus positif Covid 19 yang sudah terkonfirmasi dan dilaporkan. Sampai saat ini, belum ada vaksin untuk mencegah infeksi virus Corona atau COVID 19. Oleh karena itu, cara pencegahan yang terbaik adalah dengan menghindari faktor-faktor yang bisa menyebabkan kita terinfeksi virus ini dan menerapkan perilaku disiplin serta patuh terhadap peraturan pemerintah [2].

Analisis survival (survival analysis) adalah kumpulan prosedur statistika untuk menganalisis data dimana variabel respon adalah waktu sampai terjadinya suatu peristiwa tertentu. Wakt survival dapat diukur dalam hitungan tahun, bulan, minggu, atau hari dari awal tindak lanjut seseorang hingga suatu peristiwa terjadi. Peristiwa dapat berupa kematian, penyakit, pemulihan atau pengalaman apapun yang mungkin terjadi pada seseorang [3].

Metode Kaplan Meier yang merupakan salah satu metode pada analisis survival adalah salah satu metode analisis ketahanan hidup, dimana metode analisisnya melalui estimasi kurva dari fungsi survivalnya. Pendugaan menghasilkan selang kepercayaan waktu bertahan hidup pasien Covid 19. Uji Log Rank atau log-rank test adalah uji statistik untuk membedakan atau membandingkan kurva survival bermakna atau tidak antara dua kelompok [4].

Covid 19, metode Kaplan Meier, dan Uji Log Rank sebelumnya sudah pernah diteliti. Peneliti yang meninjau Covid 19 dilakukan oleh [5], hasil penelitian ini yaitu ribuan orang telah terinfeksi virus Covid 19 dan vaksin untuk virus ini belum ditemukan. Penelitian yang berkaitan dengan metode Kaplan Meier dan Uji Log Rank dilakukan oleh [6] untuk meneliti pasien diare anak di Rumah Sakit Islam Jakarta, hasil yang diperoleh yaitu peluang sembuh dari pasien jenis kelamin laki-laki lebih kecil daripada perempuan. Selanjutnya [7] menggunakan metode Kaplan Meier dan Uji Log Rank untuk menganalisis pasien penyakit jantung koroner di RSUD Undata Palu, hasilnya pasien jantung koroner mampu bertahan hidup hingga dua tahun. Berdasarkan penelitian sebelumnya, maka pada artikel ini akan dibahas tentang analisis survival pasien COVID 19 di kabupaten Jember menggunakan metode Kaplan Meier dan Uji Log Rank berdasarkan faktor usia dan jenis kelamin.

\section{METODE PENELITIAN}

\section{Coronavirus}

Coronavirus merupakan virus RNA strain tunggal positif, berkapsul, dan tidak bersegmen. Coronavirus tergolong ordo Nidovirales, keluarga Coronaviridae. Sifat dari virus corona yaitu sensitif terhadap panas dan secara efektif dapat diinaktifkan oleh desinfektan mengandung klorin, pelarut lipid dengan suhu $56^{\circ} \mathrm{C}$ selama 30 menit, 
eter, alkohol, formalin, dan kloroform. Virus corona ini sering menginfeksi hewan dan bersikulasi di hewan. Sehingga tidak menutup kemungkinan yang bertindak sebagai vektor yang mentransmisikan penyakit Covid 19 ke manusia yaitu hewan liar yang membawa pantogen [8].

\section{Analisis Survival}

Misal $T$ adalah variabel random nonnegatif yang menunjukkan waktu tahan hidup dari individu-individu dalam populasi. Karena $T$ variabel nonnegatif maka semua fungsi yang berhubungan dengan $T$ hanya akan didefinisikan dalam interval -.-. . Fungsi-fungsi tersebut adalah fungsi densitas probabilitas, fungsi distribusi kumulatif dan fungsi tahan hidup.

Fungsi tahan hidup, $S(t)$ didefinisikan sebagai probabilitas bertahan hidup di atas waktu $t$ [9].

$S(t)=\operatorname{Pr}[T>t]=1-\operatorname{Pr}[T \leq t]=1-F(t)=1-\int_{0}^{t} f(x) d x=\int_{0}^{\infty} f(x) d x$

Dalam hal ini fungsi tahan hidup $S(t)$ merupakan fungsi kontinu monoton turun yang mempunyai sifat

(i). $S(0)=1$, artinya peluang suatu individu bertahan hidup lebih lama dari waktu nol adalah 1.

(ii). $S(\infty)=0$, artinya peluang suatu individu bertahan hidup pada waktu yang tak terhingga adalah $0 . \quad$ [10].

\section{Metode Kaplan Meier}

Menurut [11], metode Kaplan-Meier atau product-limit diperkenalkan pertama kali oleh Kaplan Meier pada tahun 1958. Metode Kaplan Meier adalah modifikasi dari fungsi tahan hidup yang digunakan untuk menangani masalah data tidak lengkap. Manfaat penggunaan metode ini yaitu dapat memberikan estimasi peluang tahan hidup. Metode Kaplan Meier memberikan representasi grafis tentang distribusi tahan hidup. Jika tidak terdapat observasi tersensor maka fungsi tahan hidupnya adalah.

$$
S(t)=\frac{\text { banyak objek yang masih hidup } \geqslant t}{n}, t \geqslant 0
$$

\section{Uji Log Rank}

Uji Log Rank merupakan metode statistik nonparametrik, yang digunakan untuk membandingkan distribusi survival dari dua sampel dan biasanya dalam uji klinis untuk mengetahui tingkat kemanjuran pengobatan baru dibandingkan dengan pengobatan control. Uji ini terkadang disebut tes Mantel-Cox, Nathan Mantel, dan David Cox . Tes Log Rank juga dapat dilihat sebagai uji Cochran-Mantel-Haenszel yang bertingkat waktu [12].

\section{HASIL DAN PEMBAHASAN}

\section{Deskripsi Data}

Data penelitian yang akan digunakan yaitu data pasien Covid 19 di Kabupaten Jember yang diambil langsung dari web resmi data pemantauan Covid 19 pada tanggal 17 Juni 2020. Pada bagian pembahasan ini akan dijelaskan karakteristik pasien Covid 19 berdasarkan variabel jenis kelamin dan usia. Adapun berikut deskripsi data untuk setiap variabelnya. Untuk variabel usia, peneliti membagi menjadi 8 kelompok, yaitu kelompok usia , $\leq 5,6-19,20$ 29, 30-39, 40-49, 50-59, $\geq 60$ tahun, dan tidak diketahui. Sedangkan untuk variabel jenis kelamin peneliti mengelompokkan menjadi tiga yaitu tidak diketahui, lakilaki, dan perempuan. Berikut deskripsi untuk setiap variabel.

Tabel 1. Jumlah Pasien Positif Covid 19 Berdasarkan Jenis Kelamin

\begin{tabular}{cc}
\hline Jenis Kelamin & Jumlah \\
\hline Laki-laki & 44 \\
Perempuan & 20 \\
Tidak diketahui & 26 \\
\hline
\end{tabular}

Tabel 2. Jumlah Pasien Positif Covid 19 Berdasarkan Usia

\begin{tabular}{cc}
\hline Usia (Tahun) & Jumlah \\
\hline$\leq 5$ & 2 \\
$6-19$ & 7 \\
$20-29$ & 7 \\
$30-39$ & 10 \\
$40-49$ & 14 \\
$50-59$ & 11 \\
$\geq 60$ & 8 \\
Tidak diketahui & 31 \\
\hline
\end{tabular}

Tabel 3. Jumlah Pasien Positif Covid 19 Berdasarkan Jenis Kelamin dan Usia

\begin{tabular}{|c|c|c|c|c|c|}
\hline \multicolumn{2}{|c|}{ Variabel } & \multirow[b]{2}{*}{ Laki-laki } & \multirow[b]{2}{*}{ Perempuan } & \multirow[b]{2}{*}{ Tidak Diketahui } & \multirow[t]{2}{*}{ Total } \\
\hline & & & & & \\
\hline Usia & $\leq 5$ & 2 & - & - & 2 \\
\hline \multirow{8}{*}{ (tahun) } & $6-19$ & 4 & 3 & - & 7 \\
\hline & $20-29$ & 4 & 3 & - & 7 \\
\hline & $30-39$ & 7 & 3 & - & 10 \\
\hline & $40-49$ & 9 & 4 & 1 & 14 \\
\hline & $50-59$ & 8 & 2 & 1 & 11 \\
\hline & $\geq 60$ & 4 & 3 & 1 & 8 \\
\hline & Tidak diketahui & 6 & 2 & 23 & 31 \\
\hline & tal & 44 & 20 & 26 & 90 \\
\hline
\end{tabular}

\section{Analisis Metode Kaplan Meier}

Peneliti menggunakan empat variabel yaitu patients, age, sex, dan kejadian (event). Event memiliki tiga kategori, yaitu 0 untuk meninggal, 1 untuk sembuh, dan 2 untuk pasien yang masih dirawat. Analisis pertama akan digunakan variabel sex sebagai faktornya, sehingga hasilnya seperti pada Gambar 1 . 


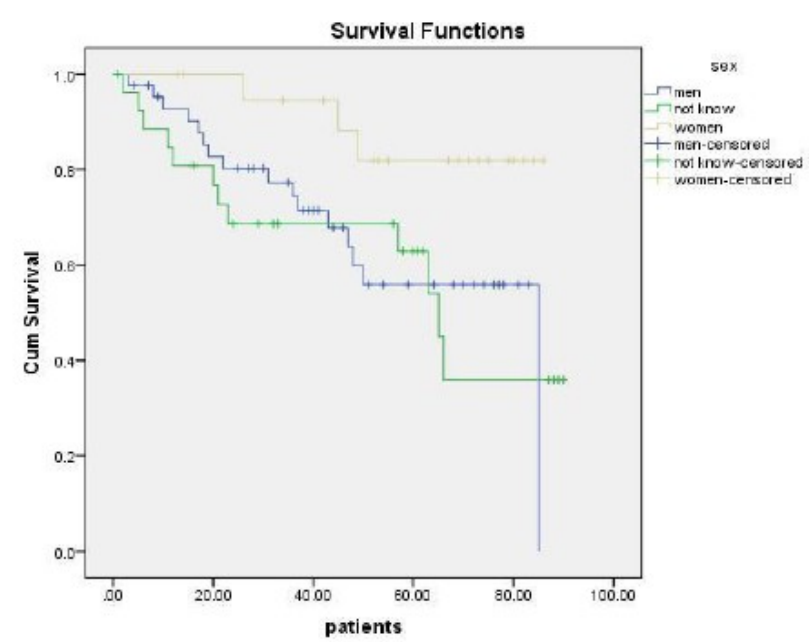

Gambar 1. Hasil Analisis Variabel Jenis Kelamin

Pada gambar di atas diperoleh grafik survival dengan keterangan warna biru yang merepresentasikan laki-laki, kuning merepresentasikan perempuan, dan hijau untuk jenis kelamin yang tidak diketahui Jika dilihat hasil analisis survivalnya dapat disimpulkan bahwa pasien Covid 19 terbanyak berjenis kelamin laki-laki dan memiliki peluang tahan hidup lebih baik dibandingkan perempuan karena jumlahnya lebih banyak. Hal ini dibuktikan pada grafik Kaplan Meier kurva jenis kelamin laki-laki berada di bawah kurva perempuan, artinya kelompok pasien laki-laki memiliki peluang sembuh lebih besar dari perempuan sehingga apabila pasien memiliki peluang sembuh lebih besar maka kasus positif Covid 19 akan berkurang.

Langkah selanjutnya analisis data pasien COVID 19 menggunakan variabel usia. Variabel usia dikelompokkan menjadi 8 golongan yang bernilai 0-7.
0: 0 -5 tahun
1: 20-29 tahun
3: $30-39$ tahun
4: $40-49$ tahun
5: 50-59 tahun
$6:>60$ tahun
7: tidak diketahui

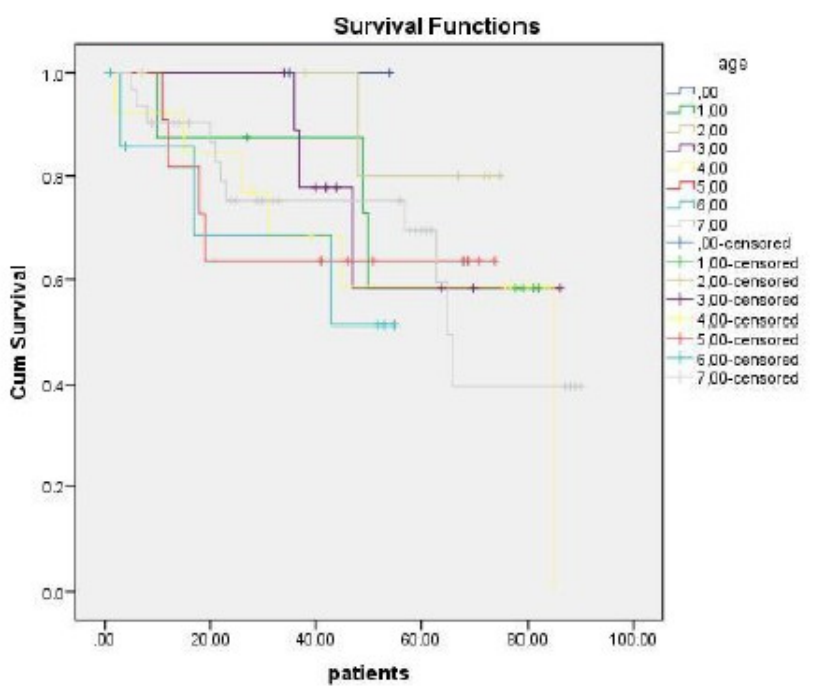

Gambar 2. Hasil Analisis Variabel Usia
Berikut penjelasan dari masing-masing warna pada gambar grafik di atas.
Golongan 0 : warna biru tua
Golongan 1 : warna hijau
Golongan 2: warna coklat
Golongan 3 : warna ungu
Golongan 4 : warna kuning
Golongan 5 : warna merah
Golongan 6 : warna biru muda
Golongan 7 : warna abu-abu

Pasien Covid 19 terbanyak yaitu berusia 40-49 tahun yang berada di golongan 4. Selain itu pasien dengan rentang usia 40-49 tahun memiliki peluang tahan hidup lebih baik dibandingkan rentang usia lainnya karena jumlah pasien ini lebih banyak. Hal ini dibuktikan pada grafik Kaplan-Meier kurva rentang usia 40-49 tahun berada di bawah kurva rentang usia lainnya, artinya kelompok pasien ini memiliki peluang sembuh lebih besar daripada kelompok lainnya.

\section{Analisis Uji Log Rank}

Uji Log Rank yang akan peneliti gunakan yaitu untuk menganalisis data pada dua kelompok yang berkaitan namun dengan kondisi yang berbeda. Dua kelompok yang dimaksud yaitu variabel usia dan jenis kelamin. Hasil analisis ini pada pasien Covid 19 di Kabupaten Jember dapat dilihat pada tabel berikut.

$H_{0}$ : tidak ada perbedaan yang signifikan antara dua variabel $H_{1}$ : ada perbedaan yang signifikan antara dua variabel

Tabel 4. Uji Log Rank Setiap Variabel Bebas

\begin{tabular}{lccl}
\hline \multirow{2}{*}{ Variabel } & \multicolumn{2}{c}{ Log-Rank } & Kesimpulan \\
\cline { 2 - 3 } & P-Value & Sig & \\
\hline Jenis Kelamin & 0.1 & 0.05 & Gagal Tolak $H_{0}$ \\
Usia & 0.376 & 0.05 & Gagal tolak $H_{0}$ \\
\hline
\end{tabular}

Berdasarkan tabel hasil Uji Log Rank di setiap variabel, maka diperoleh nilai P-Value $>\alpha(0,05)$. Maka sesuai aturan penarikan kesimpulan yaitu gagal tolak $\mathrm{H} 0$ atau dengan kata lain terima H0. Ini artinya tidak ada perbedaan yang signifikan antara kedua variabel, yaitu antara variabel jenis kelamin dan usia.

\section{KESIMPULAN}

Berdasarkan hasil dan pembahasan, hasil analisis menggunakan metode Kurva Kaplan Meier, pasien dengan jenis kelamin laki-laki mempunyai peluang sembuh lebih cepat dibandingkan dengan pasien jenis kelamin perempuan dan pasien dengan interval usia 40-49 tahun mempunyai peluang sembuh lebih cepat dibandingkan interval usia lainnya, sedangkan Uji Log Rank tidak memberikan hasil yang signifikan. Jadi metode Kurva Kaplan Meier lebih sesuai untuk menganalisis data pasien Covid 19 di Kabupaten Jember dibanding Uji Log Rank.

\section{DAFTAR PUSTAKA}

[1] Burhan, E., dkk. 2020. Panduan Praktik Klinis: Pneumonia 2019-nCoV. PDPI, Jakarta.

[2] Yahya, A. https://nasional.kompas.com/read/2020/06/18/154255 01/update 
total-ada-42762-kasus-Covid19-di-indonesiabertambah-1331 page $=$ all , diakses pada tanggal 18 Juni 2020.

[3] Kleinbaum, D. G., and Klein, M. 2012. Survival Analysis: A Self-Learning Text. Second Edition. Springer and Business Media, Inc., New York.

[4] Collet, D. 2003. Modelling Survival Data in Medical Research. Chapman and Hall, USA.

[5] Yuliana. 2020. Corona Virus Diseases (Covid 19); Sebuah Tinjauan Literatur. Wellness and Healthy Magazine. 2(1): 187-192.

[6] Muhajir, M. 2018. Analisis Survival terhadap Pasien Diare Anak Menggunakan Metode Kaplan Meier dan Uji Log Rank. Jurnal Ilmu-Ilmu MIPA. 18(1): 74-84.
[7] Suhartini, A. 2018. Analisis Kurva Survival Kaplan Meier Menggunakan Uji Log Rank. Jurnal Gaussian. 7(1): 33-42.

[8] Wang, Z., Qiang, W., and Ke, H. 2020. A Handbook of 2019-nCoV Pneumonia Control and Prevention. Hubei Science and Technologi Press., China.

[9] Nelson, W. 1982. Applied Life Data Analysis. John Wiley and Sons, Inc., New York.

[10] Lawless, J. F. 1982. Statictical Model and Methods for Lifetime Data. John Wiley and Sons, New York.

[11] Lawless, J. F. 2003. The Statistical Analysis of Recurrent Event. Springer Science and Business Media, Inc., New York.

[12] Le, C. T. 1997. Applied Survival Analysis. John Willey and Sons, Inc., New York. 